\title{
LEARNING TO DESIGN IN A SERIOUS GAME
}

\author{
Markus VOß ${ }^{1}$, Hulusi BOZKURT ${ }^{1}$, Thorsten SAUER ${ }^{2}$ and Marc NUTZMANN ${ }^{2}$ \\ ${ }^{1}$ DHBW Baden-Wuerttemberg Cooperative State University Mannheim, Germany \\ 2DHBW Baden-Wuerttemberg Cooperative State University Ravensburg, Germany
}

\begin{abstract}
This paper describes, discusses and reflects how a second-year Engineering Design project in a Mechanical Engineering bachelor's programme has been 'gamified' by introducing 'playful' elements into the course (which already incorporates Problem-Based and Project-Oriented Learning). One of the aims for reorganising the course has been to intensify its immersive character. Conducting the project in the form of a Serious Game also helped to place emphasize on the inevitable necessity of considering economic efficiency in the design process. Thus, the course provided a free space for experiencing personally that development should not necessarily strive for the technically best solution but for one that is largely accepted by the market and thus invited students to explore the perspectives of different stakeholders in the design process. Therefore, this paper gives an overview of Game-Based Learning in higher education, presents exemplarily how a design-related project course can be reorganised as a Serious Game, provides indications for the inclusion of measurable project out-comes in the course grading, and shares experiences made during the supervision of the course.
\end{abstract}

\section{Keywords: Serious games, Game-Based Learning, engineering design}

\section{INTRODUCTION}

This article reports on the continuous development of a lecture series in Engineering Design over a span of the last ten years. Problem-Based Learning was - as it has been in many other universities - the core that helped to put the students in the centre of the learning process. Initially, we started to investigate the beneficial effects of Project-Oriented Learning [1]. Later we have expanded the idea to allow the students to gain Design-Build-Test experiences [2, 3]. The introduction of testing own designs also opened a door in the assessment of learning outcomes in the way that students can get feedback directly from their product (and do not rely uniquely on the educator's judgement anymore) [4, 5]. This equally effects the way in which we, as educators can reflect the alignment of the learning assessment with the desired learning outcomes [6]. Recently, we have studied how students perceive the differences in these learning approaches [7]. Now, we want to enlarge the framework when we add a playful element in our Engineering Design projects and explore Game-Based Learning.

\section{PUTting PLAYFULNESS INTO LEARNING ACTIVITIES}

Unfortunately, trying to fathom scientifically what playing is exactly, what distinguishes a serious game from a casual one and how education can take pedagogic advantage of using game elements comes near to facing the 'Babel problem' [8]. The following sections are an attempt to define the basic terms.

\subsection{An ancient socio-cultural technique: playing and gaming}

What are games? The word 'game' itself is used in everyday language as well as in the terminology of diverse professions with a great wealth of nuances. Therefore, it is advisable to lay down first what is meant by a 'game' in the context of this contribution.

Built on the theories of the Dutch cultural philosopher and historian Johan Huizinga [9], the French sociologist Roger Caillois [10] distinguishes between playing and gaming, see Figure 1. Both concepts can be seen as the two poles of a continuum of various forms of playing. At one end, Caillois places rather unstructured and spontaneous activities (that express a certain playfulness) for which he uses the Ancient Greek word $\pi \alpha l \delta i \alpha$ (paidia, meaning playing). At the other end of the continuum, he refers to structured activities with explicit rules by the Latin word ludus (meaning gaming). Based on a comprehensive synopsis of these two and many other authors, Salen Tekinbaş and Zimmerman [11] give a 
'more technical' definition of what a game is. They define a game to be 'a system in which players engage in an artificial conflict, defined by rules, that results in a quantifiable outcome'.

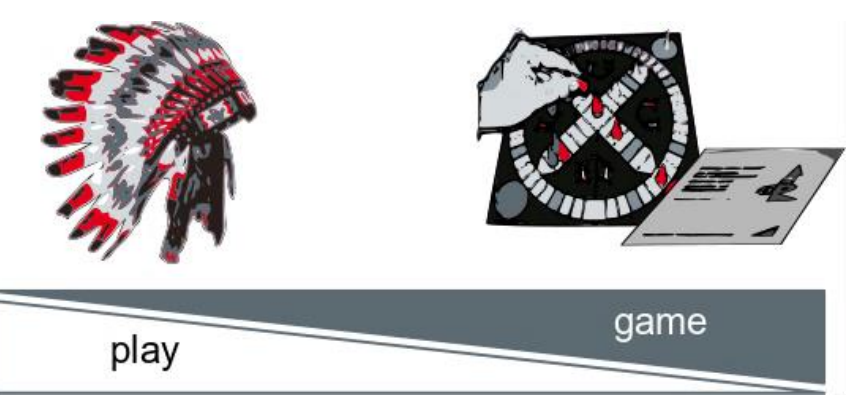

Figure 1. Play and game as antagonistic concepts

A further characterisation marks off four elementary forms of play, described by the Ancient Greek

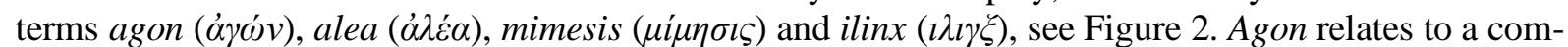
petitive element. Alea adds chance. Mimesis (or mimicry) involves role-playing. And ilinx - the Greek word for 'whirlpool' - designates the loss-of-control (in the sense of altering perception).
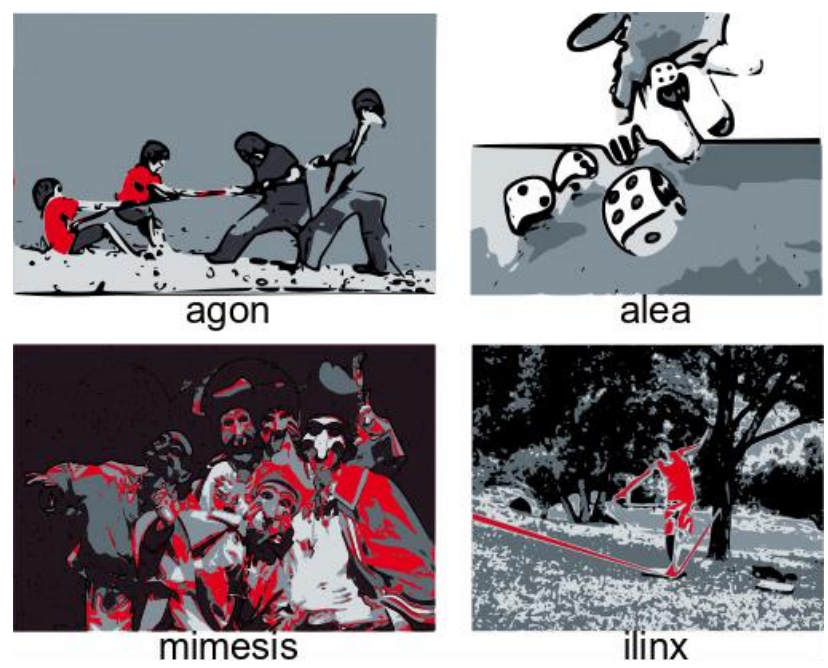

Figure 2. Forms of play

Design contests are good examples for academic attempts of introducing agonistic elements in Design Education $[12,13]$. The authors also observe that this whirls the competing participants round (ilinx) and engages them in the contest.

\subsection{The reunion of action and thought: serious games}

Abt [14] differentiates between games that 'may be played seriously or casually'. For games that 'have an explicit and carefully thought-out educational purpose and are not intended to be primarily for amusement' he coined the term serious games. Abt also draws attention to the fact that 'even relatively simple [...] games are sufficiently rich in content to provide different levels of learning simultaneously'. Accordingly, slow learners can focus on rather 'concrete, static elements of the game'. Whereas, moderately fast learners will be able to 'develop [...] cause and effect chains and attempt to apply them'. And the most advanced learners will concurrently pursue several strategic options in 'parallel causal chains'.

\subsection{Sugaring the pill: Game-Based learning}

The term gamification simply refers to the use of game elements in non-game contexts [15]. When game elements are brought into education with the intention of activating learning, the resulting pedagogy is called Game-Based Learning.

In other scientific domains, gamification has led to numerous educational applications in the past - such as business simulations and interactive healthcare games. But in the field of Engineering Design there was previously still little use of Game-Based Learning. Some examples from literature include teaching 
Knowledge Management [16], Eco-design [17, 18], Product-Service Systems [19], Innovation Processes [20] and Lean Product Development [21].

\section{FRAMEWORKS}

\subsection{Course description}

DHBW Cooperative State University offers engineering education programmes that markedly promote alternative learning approaches. Expressed in accredited workload, Engineering Design takes an important position throughout the whole three-year long bachelor's programme in Mechanical Engineering. This article reports on a third semester lecture on Machine Elements that is supplemented by an Engineering Design Project. Technically, the course focuses inter alia on metal springs and the dimensioning of shafts.

\subsection{Learning objectives}

In previous work, we have already pointed out beneficial effects of student-centred learning approaches [1] involving design-build-test experiences [2,3]. In addition to previous objectives, the 'gamification' of the Engineering Design Project aims at making our students.

- engage more thoroughly (intensifying the immersive character of the course)

- consider economic efficiency

- explore the perspectives of different stakeholders

in the design process, cf. Figure 3.

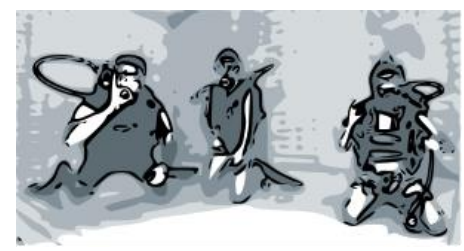

(a)

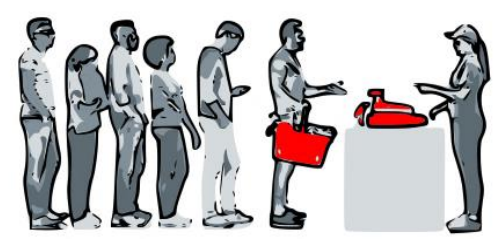

(b)

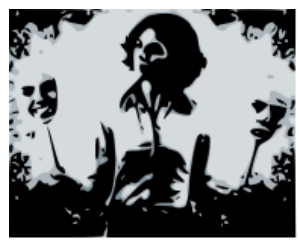

(c)

Figure 3. Learning objectives: a) Immersion in the task, b) learning to sell ideas and c) role-swapping

\subsection{Methodology}

In the set-up of our course we already gained the most distinctive change towards student-centred learning by formulating open-ended problems that resemble real-world applications. Problem-Based Learning therefore is a platform on which the other learning approaches we use are piled on top of each other, see Figure 4. Project orientation adds group collaboration but still students persist in experiencing design projects where nothing is built ('virtual' projects) as an artificial paper-chase game. The main pedagogic gain from Design-Build-Test experiences is that the experiments enable the students to learn from own mistakes. 'Gamifying' our course hopefully intensifies interactions between students as they have to 'play' different roles in the design process.

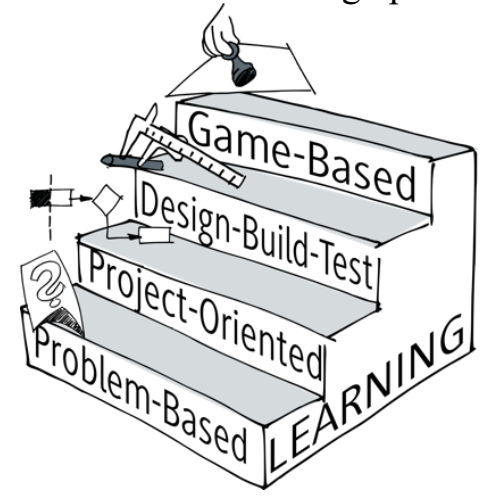

Figure 4. Learning approach hierarchy

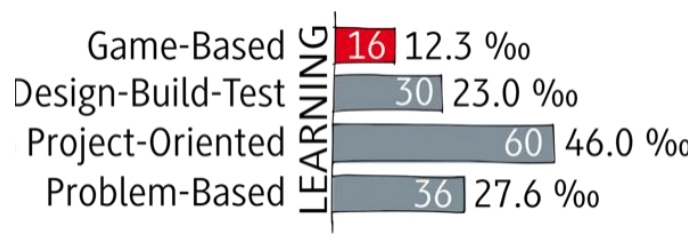

Figure 5. Learning approaches in the E\&PDE conference proceedings 
This graduation of learning approaches also seems to exist within the research presented at the E\&PDE conference, cf. Figure 5. Among the totality of 1305 publications currently accessible in the publication's repository [22] of the Design Society, the vast majority of those that address learning approaches are dealing with Problem-Based (36) and Project-Oriented Learning (60). Design-Build-Test experiences (including experiential learning) attract far less interest (30). In comparison, Game-Based Learning (16) rather is the wallflower among the learning approaches.

\section{IMPLEMENTATIONS}

In last year's autumn term, the course was attended by 63 students from three classes with different specialisation (Engineering Design and Process Engineering). In the Engineering Design Project, students worked in ten mixed-up teams. In the design brief, we asked the students to develop a device for winding up helical compression springs (of a given size 0.63 x D x 20), see Figure 6.

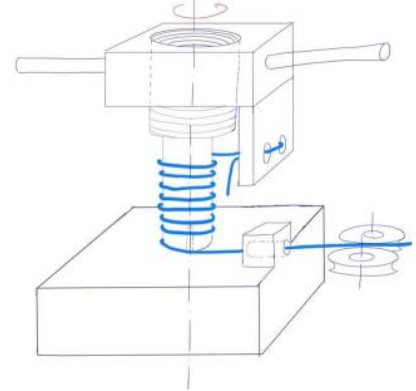

(a)

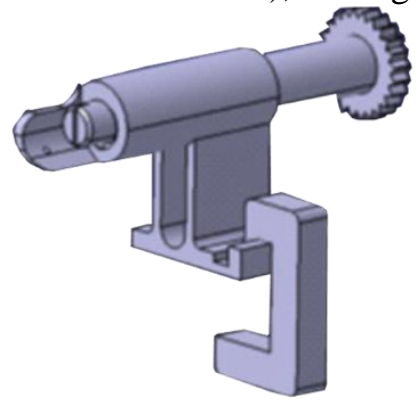

(b)

Figure 6. a) Student concept [23] and b) CAD model [24] of a spring winder

Project planning was governed by tight time constraints, cf. Figure 7. It made the students go through a whole product development process within eight weeks only. Briefings (represented by open symbols in the project plan) generally have been given just one week before the corresponding milestone (filled symbols) was due. The project was structured according to the $\mathrm{V}$ model [25] which describes a generic procedure for designing systems in a cross-domain approach. The strength of the $\mathrm{V}$ model is that it forces to check the progress made in the design continuously.

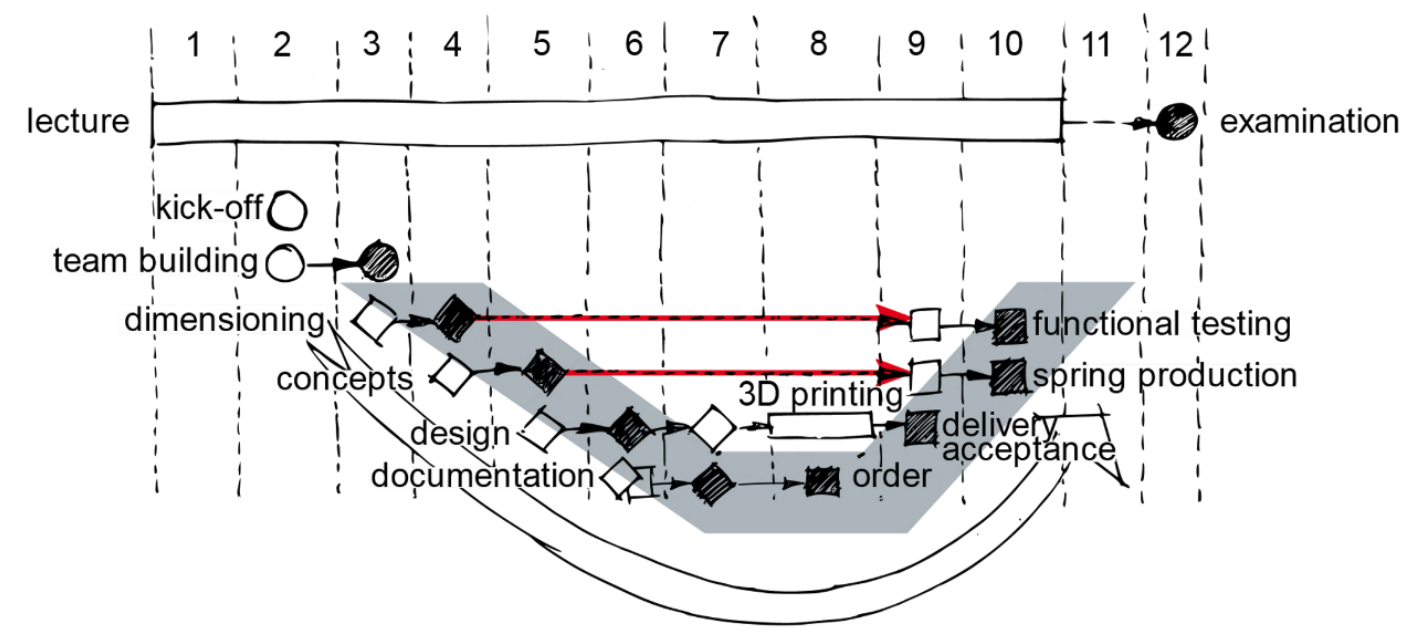

Figure 7. Project plan

One characteristic feature of the game-based project was that the teams swapped roles after half of the time. First, all teams were developing their spring winder (corresponding milestones marked by 'diamonds' in the project plan). Later, they assumed the role of a company that orders the device and manufactures springs with it (milestones denoted by upright squares).

Thus, the purchase decision from the ordering party had to be made solely on basis of the product documentation that the developers furnished. It was only one week later that the spring winders had to be produced by additive manufacturing (fused filament fabrication). Also, the dimensioning of the elastic properties of the spring that the producer of the device has made at the beginning of the project was 
validated when the 'buyer' of the device tested if the spring complies with the mutually agreed requirements at the end of the project, see Figure $8 \mathrm{~b}$. In the same way, practical testing also revealed that the concepts of the ten groups differed widely in terms of manufacturing time, see Figure 8a.

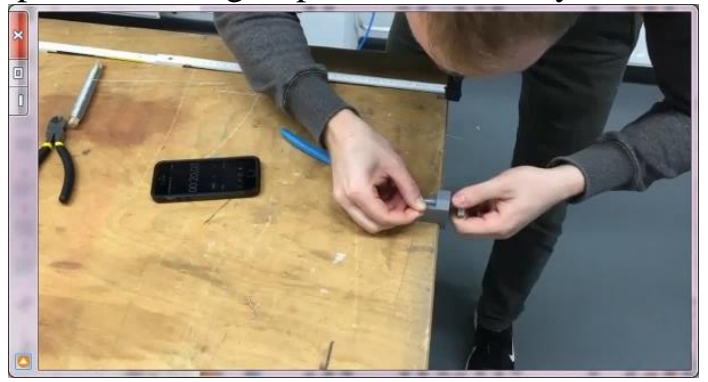

(a)

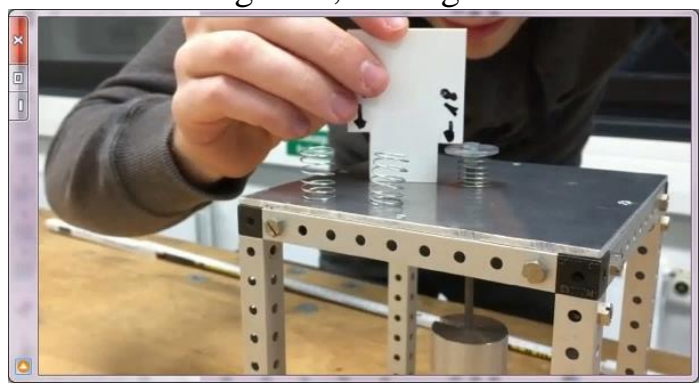

(b)

Figure 8. Video-selfie [26]: a) verifying the manufacturing time for winding the spring and $\mathrm{b}$ ) testing the travel of the spring under specified load

\section{CONCLUSIONS}

The paper outlined how a design-related course has been 'gamified'. Of course, a single run is not enough to draw final conclusions. But what we already can say is that the game character kindled a lot of enthusiasm among the students and made some nearly forget (caught in an enormous ilinx) that their assignment is just a simulation of the design process. Competition between the teams (agonistic element) also incited motivation to create innovative solutions. Role repartition (mimesis) between a developing and an ordering party helped to find out that solutions in general should not be too complicated but always a compromise between technical feasibility and customer request.

Game-Based Learning also opened new doors for learning assessment - putting students (and not teachers) in the active role of exploring why some solutions work better than others. Especially the number of orders that a team got (or did not get) from other teams gave honest and sustainable feedback in an n-to-n relationship. Discussions of that cardinality are much richer than a judgement that an educator can ever make.

Naturally, games also incite discussions on decisions that some find to be aleatory. In last year's cohort a student for example refused (temporarily but very resolutely) to accept it as an engineering task not only to execute calculations but also to reflect on what is necessary to calculate. But in respect to our research, we are chuffed to record that this criticism rather concerned traditional grading of a report. However, measurables from the game, such as the cost-income-ratio for the device manufacturer and for the 'spring winder', that have been included in the grading, were generally very well-accepted by the participants.

Obviously, there is still more to discover on how novice designers can gain practice through serious games. Future research will therefore be directed towards investigating the students' perception of serious games in a comparative survey.

\section{REFERENCES}

[1] Voß M. Students Response to open-ended problems in an Engineering Design Project. In International Conference on Engineering and Product Design Education, E\&PDE'12, Antwerp, September 2012, pp.343-348 (The Design Society, Glasgow).

[2] Voß M., Bozkurt H. and Sauer T. Make your bed and lie in it! Learning to take the consequences of design decisions in an Engineering Design project. In International Conference on Engineering and Product Design Education, E\&PDE'15, Loughborough, September 2015, pp.400-405 (The Design Society, Glasgow).

[3] Voß M. and Bozkurt H. On a scalable Design-Build-Test experience that challenges students and staff. In EAEEIE Annual Conference, EAEEIE'15, Copenhagen, July 2015, (European Association for Education in Electrical and Information Engineering).

[4] Voß M., Bozkurt H. and Sauer T. Grading Engineering Design Projects. Let products give feedback! In International Conference on Engineering and Product Design Education, E\&PDE'16, Aalborg, September 2016, pp.442-447 (The Design Society, Glasgow).

[5] Sauer T., Voß M., Bozkurt H. and Nutzmann M. Experiences with Direct Product Feedback in courses on Engineering Design. In International Conference on Engineering and Product Design Education, E\&PDE'18, London, September 2018, pp.50-55 (The Design Society, Glasgow). 
[6] Voß M., Bozkurt H. and Sauer T. Aligning assessment results with learning outcomes. In International Conference on Engineering and Product Design Education, E\&PDE'17, Oslo, September 2017, pp.424-429 (The Design Society, Glasgow).

[7] Voß M., Bozkurt H. and Sauer T. How students perceive different learning approaches. In EAEEIE Annual Conference, EAEEIE'18, Reykjavík, September 2018, (Institute of Electrical and Electronics Engineers, New York).

[8] Aldrich C. The complete guide to Simulations and Serious Games. How the most valuable content will be generated in the age beyond Gutenberg to Google, 2009 (John Wiley \& Sons, San Francisco).

[9] Huizinga J. Homo ludens. Proeve eener bepaling van het spel-element der cultuur (in Dutch: Homo ludens. A study of the play-element in culture), 1938 (Tjeenk Willink, Haarlem).

[10] Caillois R. Les jeux et les hommes (in French: Man, play and games), 1958 (Gallimard, Paris).

[11] Salen Tekinbaş K. and Zimmerman E. Rules of play, Game Design fundamentals, 2004 (MIT, Cambridge, MA).

[12] Dick M. and Birkhofer H. Design is fun! Experiences from a student design contest at Darmstadt University of Technology. In International Conference on Engineering Design, ICED'03, Stockholm, August 2003 (Professional Engineering Publishing, Bury St Edmunds).

[13] van Breemen J.J., Jansen A.J. and de Geus S. Contests make better engineers. Participation in design contests contributes to the education of engineering designers. In International Conference on Engineering Design, ICED'97, Tampere, August 1997, pp.519-522 (Heurista, Zurich).

[14] Abt C.C. Serious Games, 1970 (Viking, New York).

[15] Deterding S., Dixon D., Khaled R. and Nacke L. From Game Design elements to gamefulness. Defining Gamification. In International Academic MindTrek Conference, MindTrek '11, Tampere, September 2011, pp.9-15 (Association for Computing Machinery, New York).

[16] Stenholm D., Bergsjö D. and Catic A. Game-Based Learning of knowledge reuse in engineering education. In International Conference on Engineering Design, ICED'19, Delft, August 2019, pp.509-518 (The Design Society, Glasgow).

[17] Boks C. and McAloone T.C. The design of eco board games as a deep-learning approach to Sustainable Product Design education. In International Conference on Engineering and Product Design Education, E\&PDE'09, Brighton, September 2009, pp.390-395 (The Design Society, Glasgow).

[18] Judmaier P., Huber M., Pohl M., Rester M. and Leopold D. Sustainable living. A multiplayer educational game based on Ecodesign. In International Conference on Engineering and Product Design Education, E\&PDE'08, Barcelona, September 2008, pp.734-739 (The Design Society, Glasgow).

[19] Meuris D., Herzog M., Köster M. and Sadek T. Playful conceptual design of industrial productservice systems. An experiment. In International Conference on Engineering Design, ICED'13, Seoul, August 2013, pp.339-348 (The Design Society, Glasgow).

[20] Ma Y., Vallet F., Cluzel F. and Yannou B. Analysing the relevance of serious game elements for effectively teaching innovation processes. In International Conference on Engineering Design, ICED'19, Delft, August 2019, pp.439-448 (The Design Society, Glasgow).

[21] Blanco E., Berard S., Blanco S., Chevrier P., Heidsieck E., Kenwright J. and Verges V. Designing experiential training in Lean Product Development. A collaboration between industry and academia. In International Conference on Engineering and Product Design Education, E\&PDE'19, Glasgow, September 2019 (The Design Society, Glasgow).

[22] Publications repository on the website of the Design Society. https://www.designsociety.org /group/18/Search+DS+publications [Accessed on 2019, 12 December]

[23] Twele M., Haack J., Jäger L., Lohr L., Raissle L. and Valaynis V. Concepts for a spring winder. Bozkurt H. and Voß M. Engineering Design Project, 2019 (DHBW, Mech.Eng., Mannheim).

[24] Riehm D., Fehrenbach F., Kohl J., Milz R., Rogasch S. and Röll N. Spring winder. Product flyer. Bozkurt H. and Voß M. Engineering Design Project, 2019 (DHBW, Mech.Eng., Mannheim).

[25] VDI 2206 Design methodology for mechatronic systems, 2004 (Beuth, Berlin).

[26] Milz R., Fehrenbach F., Kohl J., Riehm D., Rogasch S. and Röll N. Manufacturing and functional testing of a helical compression spring (video). Bozkurt H. and Voß M. Engineering Design Project, 2019 (DHBW, Mech.Eng., Mannheim). 